\title{
Rancangan Taman Air Sungai Ciliwung pada Sempadan Sungai di Menteng, Jakarta Pusat
}

\author{
Raey Monica Flamencya S dan Endrotomo \\ Departemen Arsitektur, Fakultas Teknik Sipil dan Perencanaan, Institut Teknologi Sepuluh Nopember \\ (ITS) \\ Jl. Arief Rahman Hakim, Surabaya 60111 \\ E-mail: endrotomoits@yahoo.com
}

\begin{abstract}
Abstrak - Sungai Ciliwung Jakarta dalam sejarah merupakan kawasan yang digunakan untuk perdagangan. Tetapi, seiring berjalannya waktu, terjadi pergeseran yang membuat sungai Ciliwung menjadi kawasan yang 'ditinggalkan'. Salah satu daerah tersebut yaitu Tugu Tani dijadikan sebagai lahan studi. Obyek desain menghadiri aktivitas untuk menghidupkan daerah setempat dengan menyediakan "Taman Air Sungai Ciliwung". Desain dilakukan dengan mendekatkan obyek dan lahan eksisting yaitu sungai Ciliwung sehingga lahan studi dibagi menjadi dua kawasan yang mengapit sungai. Obyek rancang menggunakan metode perancangan ruang luar untuk mencapai tujuan dari desain bangunan yaitu kesatuan antara obyek dan lahan eksisting. Penggunaan metode menyesuaikan bentuk lahan eksisting dengan menambahkan materi baru yang didesain terbuka tanpa melepaskan kenyamanan pengunjung. Obyek desain menyediakan aktivitas rekreasi yang menggunakan elemen air dari sungai Ciliwung pada kawasan I dan aktivitas perdagangan sebagai sarana ekonomi untuk meningkatkan kualitas masyarakat setempat pada kawasan II. Kedua kawasan merupakan rancangan ruang luar yang dihubungkan dengan jembatan dan transportasi air pada sungai Ciliwung.
\end{abstract}

Kata Kunci- Sungai Ciliwung, taman air, rekreasi, air, area komersil, rancangan ruang luar.

\section{PENDAHULUAN}

SEJARAH perkembangan peradaban manusia tidak bisa $S_{\text {dilepas dari perkembangan hubungan manusia dengan }}$ alam termasuk dengan sungai. Sejak dulu, sungai telah dimanfaatkan untuk berbagai kebutuhan manusia dan pendukung utama kehidupan flora dan fauna.

Hubungan sungai dengan manusia di Indonesia juga telah ada sejak dulu. Hal tersebut dapat dilihat dari sejarah kota Jakarta yang dimulai dengan terbentuknya pemukiman di muara Ciliwung pada abad ke-15. Pemukiman tersebut bernama "Kalapa" dan merupakan sebuah bandar penting di bawah kekuasaan Kerajaan Pajajaran. Kalapa berkembang menjadi pusat kegiatan ekonomi sekaligus pusat pemerintahan yang dibangun dan dikembangkan Belanda sejak tahun 1600an melalui VOC.

Seiring perkembangan zaman, pusat peradaban kota bergeser dan meluas dari Sungai Ciliwung sehingga terdapat beberapa daerah sempadan sungai yang tertinggal dan terabaikan. Akibatnya, muncul berbagai hal negatif seperti penumpukan sampah yang menggunung sehingga sungai tidak

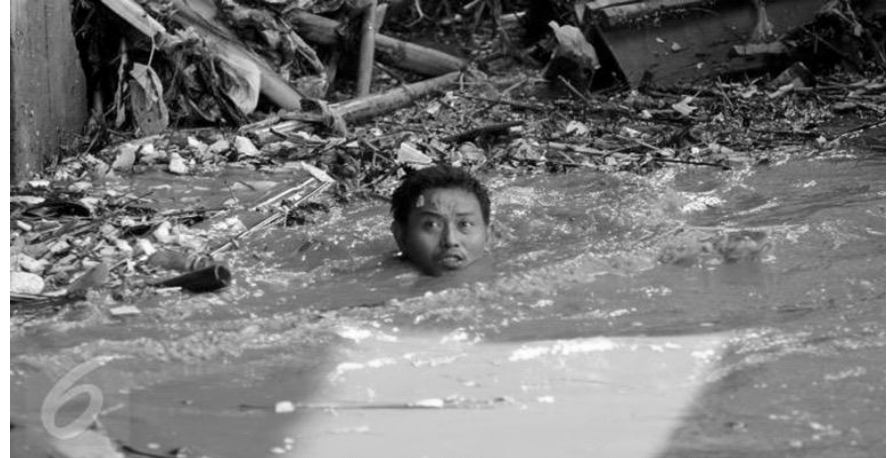

Gambar 1. Warga nekat membuka aliran sungai ciliwung yang terhambat akibat tumpukan sampah di kolong jembatan rajawati, kalibata, Jakarta, senin (16/11/2015). Sampah yang di dominasi batang bamboo akibat hujan deras, minggu $(15 / 11)$.

Sumber : Liputan6.com

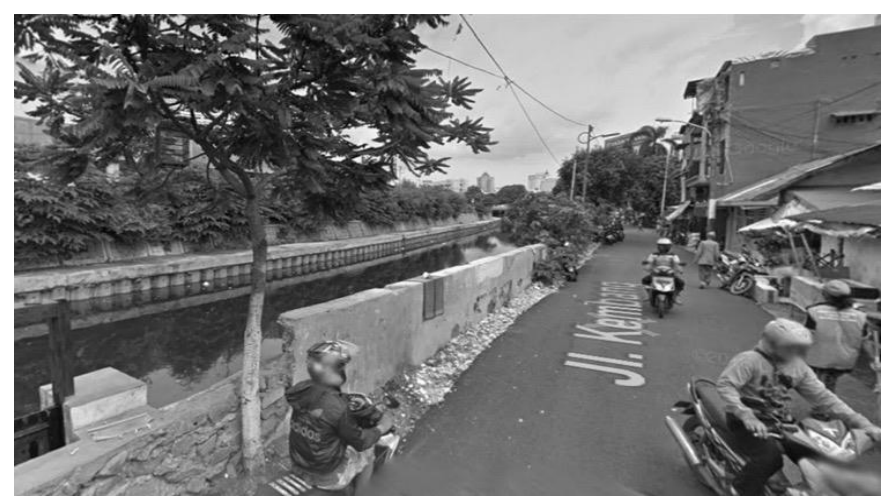

Gambar 2. Situasi pemukiman warga di sempadan sungai ciliwung kecawatan senen, Jakarta

Pusat Sumber : Google earth

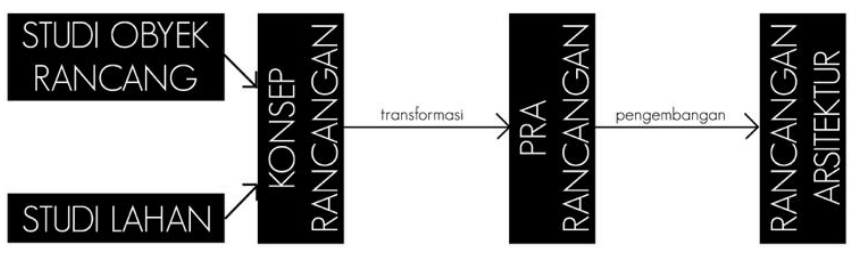

Gambar 3. Diagram Metode oleh John Zeisel 
dapat berfungsi dengan baik. Selain itu, beberapa bagian Sungai Ciliwung yang sempadannya ditempati oleh pemukiman warga menengah kebawah tetap merupakan wilayah yang "tidak terpandang" di kota Jakarta. Hal ini secara tidak langsung membatasi aktivitas kota di sepanjang sungai sehingga estetika, fungsi dan peran Sungai Ciliwung berkurang bahkan terabaikan.

\section{METODA PERANCANGAN}

\section{A. Metode John Zelsel}

Merancang menurut John Zeisel dalam buku Inquiry by Design memiliki tiga elemen dasar diantaranya imaging, presenting, testing. Studi obyek rancang yang disesuaikan dengan studi lahan yang diteliti sehingga memunculkan ide yang saling menghubungkan keduanya yaitu rekreasi kota yang berpotensi untuk ramai sehingga Sungai Ciliwung menjadi terperhatikan dan terhindar dari sampah. Ide rancang untuk mencapai sebuah rancangan arsitektur yang utuh dapat melalui proses untuk mengumpulkan fakta-fakta dan pengetahuan yang memenuhi kebutuhan rancangan.

\section{B. Anchoring}

Metode ini merupakan sebuah prinsip umum yang dipakai untuk bangunan komersil seperti mall. Penentuan sirkulasi dan setiap store pada mall ditentukan dengan cara 'anchoring'.

Obyek rancang memiliki prinsip anchoring dengan menentukan titik-titik yang berpotensi rama yang memancing pengunjung menjelajahi keseluruhan suatu rancangan menjadi sebuah metode sampingan rancangan untuk mencapai tujuan utama.

\section{Metode Teknik Perancangan Ruang Luar-Yohinobu Ashihara}

Perancangan ruang luar berarti menciptakan ruang Positif (P) atau ruang Positif-Negatif (PN) yang merupakan perpaduan antara arsitektur dengan atap dan ruang luar tanpa atap. Elemen-elemen yang dibutuhkan dalam perancangan ruang luar ialah skala dan tekstur.

Skala berupa perbandingan jarak pandang dengan ketinggian bangunan. $\mathrm{D} / \mathrm{H}=1$ merupakan batas perubahan nilai dan kualitas ruang. Teori sepersepuluh di dalam buku "The Silent Language", Edward Hall menegaskan bahwa orang telah mengembangkan daerah "teritotial"nya sampai pada suatu luasan yang sukar diduga.

Sedangkan, tekstur dan material merupakan kesan yang ingin ditampilkan pada bangunan. Hal ini juga dipengaruhi oleh jarak pandang sehingga kesan material/struktur yang ingin ditunjukkan sampai pada subyek yang melihat.

Teknik perancangan ruang luar juga memperhatikan hal berikut :

1. Merencana ruang luar

2. Meng "enclose" ruang luar

3. Tingkatan ruang luar

4. Deretan ruang luar

5. Beberapa teknik pemecahan yang lain
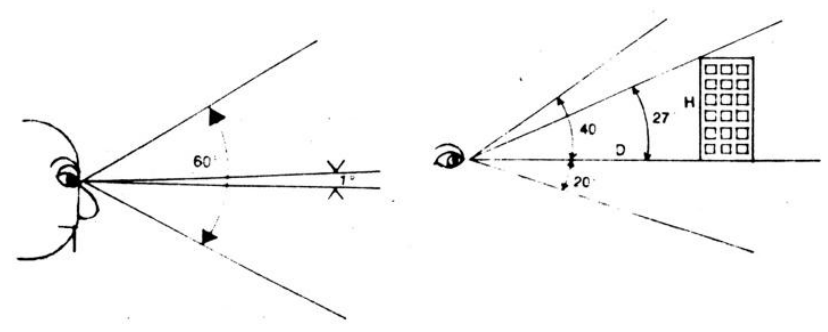

Gambar 4. Bidang Pandangan

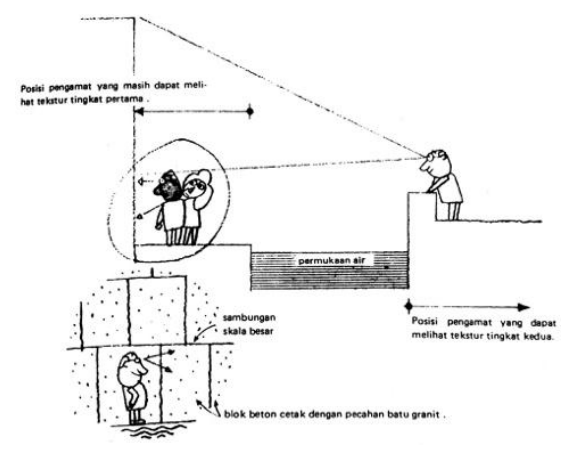

Gambar 5.Tekstur Aturan Pertama dan Aturan Kedua

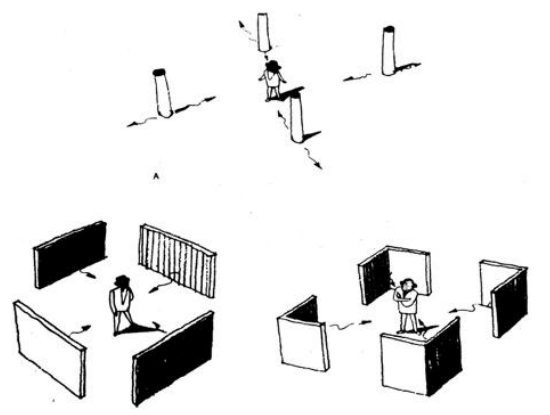

Gambar 6. Meng“enclose” Ruang
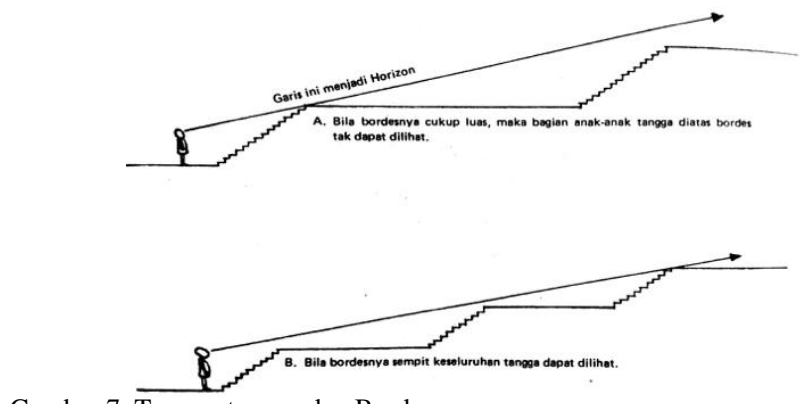

Gambar 7. Tangga-tangga dan Bordes

\section{HASIL DAN EKSPLORASI}

Obyek rancang bangunan tersorot pada lahan eksistingnya yaitu Sungai Ciliwung. Obyek merupakan salah satu penyelesaian masalah yang dialami oleh sungai. Strategi yang 
dilakukan ialah membuat bentuk bangunan dan sirkulasi yang berhubungan secara langsung dengan sungai menggunakan metode perancangan ruang luar. Metode tersebut membantu untuk menyatukan antara ruang luar bangunan ke dalam obyek desain. Dengan menghadirkan aktivitas yang terpusat pada sungai, maka masyarakat kota dapat mulai "menganggap" Sungai Ciliwung merupakan salah satu bagian dari kota Jakarta yang dapat dinikmati. Perhatian tersebut memunculkan rasa memiliki sungai bersama sehingga secara tidak langsung mengurangi keadaan sungai yang "terabaikan" oleh kota Jakarta. Hal tersebut juga dapat meningkatkan kualitas daerah sempadan sungai pada titik tertentu sebagai "pemula" yang memperkenalkan kembali tentang Sungai Ciliwung.

Arsitektur yang dihadirkan dalam obyek rancang "Taman Air Sungai Ciliwung" yang terletak di Menteng, Jakarta Pusat dipisah menjadi dua zona yaitu bagian sebelah barat dan sebelah timur sungai. Pendekatan desain diambil dari lahan eksisting. Hal tersebut membuat lahan eksisting memiliki hubungan yang erat dengan obyek rancang. Bentuk yang diambil mengikuti keadaan lahan eksisting yang disandingkan dengan metode perancangan ruang luar sehingga keterkaitan yang ingin dicapai dari pendekatan semakin kuat. Perkuatan hubungan lahan dengan obyek rancang secara langsung diterapkan dalam konsep zona. Zona dipisah menjadi dua bagian yang berada di sebelah barat (kawasan I) dan timur (kawasan II) sungai. Daerah sungai yang diapit tersebut memiliki panjang \pm 200 meter yang merupakan jarak yang nyaman untuk pejalan kaki menikmati daerah sempadan sungai.

Adapun ciri arsitektur kontekstual sebagai berikut:

- Meningkatkan kualitas lingkungan hidup daerah setempat

- Pendekatan bentuk bangunan melalui lahan eksisting yang memberikan wadah aktivitas kepada masyarakat terhadap Sungai Ciliwung dan daerah sekitarnya.

- Penggunaan elemen air yang diambil dari sungai eksisting untuk keperluan dalam bangunan, aktivitas utama serta estetika pada bangunan.

\section{A. Konsep bentuk}

Ditinjau dari ciri kontekstual :

\section{Meningkatkan kualitas lingkungan hidup daerah} setempat

Peningkatan kualitas dilihat dari faktor fisik, psikologi, sosial, ekonomi, dan budaya.

2. Pendekatan bentuk bangunan melalui eksisting yang memberikan wadah aktivitas kepada masyarakat terhadap Sungai Ciliwung dan daerah sekitarnya

Pendekatan melalui lahan eksisting dimulai dengan pembuatan sungai buatan yang memunculkan bentuk bangunan yang mengorientasikan bentuknya ke arah 'sungai. Bentuk lebih tertutup di area barat lahan dan lebih terbuka di area timur yang merupakan daerah sempadan sungai (kawasan I). Begitu pula, sirkulasi pada lahan bagian timur sungai yang terdesain terbuka namun tetap dinaungi (kawasan II).

MASALAH

RESPON

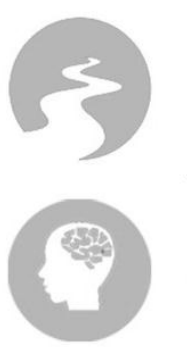

Sungai Ciliwung yang

Pembersihan dan perbaikan sungai serta lahan sekitarnya tercemar yang menjadi lahan eksisting

Perilaku masyarakat jakarta yang sibuk, kaku dan konsumtif
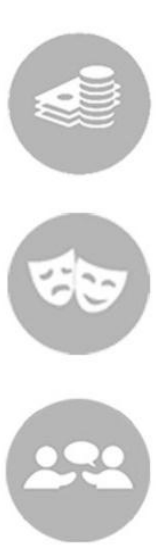

Masyarakat kota yang individualistis

Pertumbuhan ekonomi daerah setempat

\begin{tabular}{ll}
\hline & $\begin{array}{l}\text { Area publik (hiburan) mengang- } \\
\text { kat air sebagai tema bangunan }\end{array}$ \\
Budaya membuang & untuk mendekatkan pikiran mas- \\
sampah ke sungai & yakat terhadap air yang
\end{tabular}

Tabel 1: Tabel Masalah dan Rebprsih Obyek Rancang

Penyediaan area publik yang diberi fasilitas hiburan yang dikombinasi dengan area komersil

Area komersil untuk masyarakat setempat membangun kegiatan ekonomi yang difasilitasi akses dan area publik

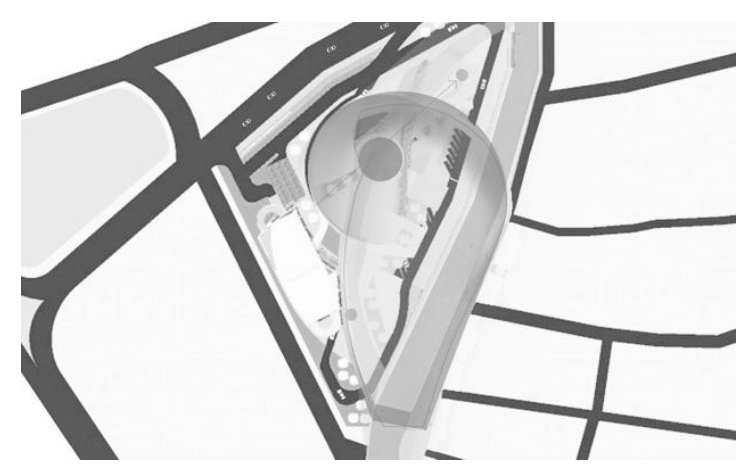

Gambar 8. Konsep Bentuk

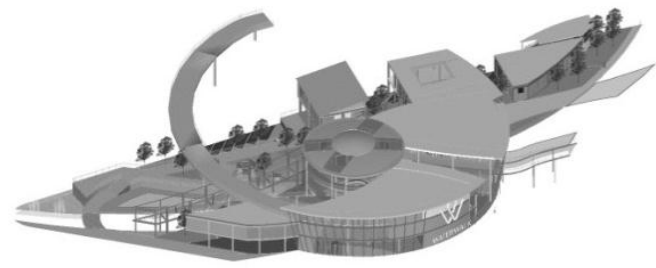

Gambar 9. Bentuk Bangunan

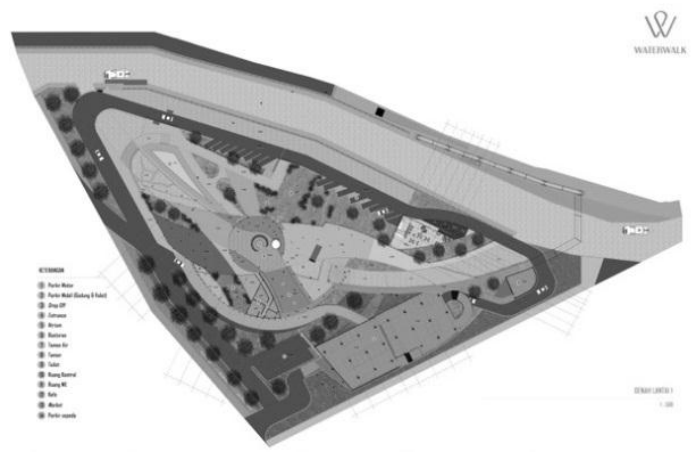

Gambar 10. Denah Lantai 1 


\section{Penggunaan elemen air}

Elemen air digunakan dari Sungai Eksisting yang dibawa ke arah sungai buatan lalu diolah. Olahan sungai diperlihatkan secara langsung kepada pengunjung sebagai bentuk edukasi. Hasil dari pengolahan sungai diarahkan kepada aktivitas utama pada bangunan yaitu wahana permainan air. Selain itu, air juga digunakan sebagai estetika bangunan seperti water curtain dan fountain.

\section{KESIMPULAN}

Sungai Ciliwung memiliki beberapa daerah yang "tak terpandang". Oleh karena itu, dibutuhkan suatu aktivitas yang dapat menggunakan Sungai Ciliwung untuk mencegah sungai kembali kotor akibat "tak terperhatikan". Aktivitas tersebut diwadahi oleh "Taman Air Sungai Ciliwung" yang didesain di daerah Menteng, Jakarta Pusat yang mengapit salah satu titik yang berada di Sungai Ciliwung. Obyek desain menarik pengunjung untuk beraktivitas berdampingan dengan Sungai Ciliwung sehingga secara tidak langsung sungai akan menjadi daerah yang terperhatikan untuk masyarakat kota Jakarta.

Obyek memberikan dua fungsi utama yaitu sebagai edukasi dan hiburan unruk pengunjung. Edukasi berupa sirkulasi yang mengarahkan pengunjung untuk melihat eksisting sungai yang akan diolah dan digunakan sebagai sebuah wahana air. Sedangkan, hiburan berupa wahana air yang dihasilkan dari proses edukasi serta area komersil yang ditawarkan kepada pengunjung seperti cafe dan tempat belanja.

\section{DAFTAR PUSTAKA}

[1] Pemerintah Republik Indonesia, Peraturan Pemerintah nomor 26 tahun 2008

[2] Pemerintah Republik Indonesia, Peraturan Pemerintah nomor 38 tahun 2011

[3] Mulyanto, H.R, 2007, Sungai Fungsi dan sifat-sifatnya, Penerbit Graha Ilmu, Yogyakarta.

[4] P. Duerk, Donna, 1993, Architectural Programming: Information Management for Design. John Wiley \& Sons. Inc.

[5] Zeisel, John, 1984, Inquiry by Design: Tools for Environment-Behavior Research.

[6] Neuferst, Ernst, 1996, Data Arsitek, Penerbit Erlangga, Jakarta.

[7] http://www.liputan6.com/

[8] http://www.tribunnews.com/

[9] http://bpad.jakarta.go.id/

[10] http://www.vietnam-guide.com/hoi-an/hoi-an-riverside.htm

[11] http://www.archdaily.com/office/snohetta

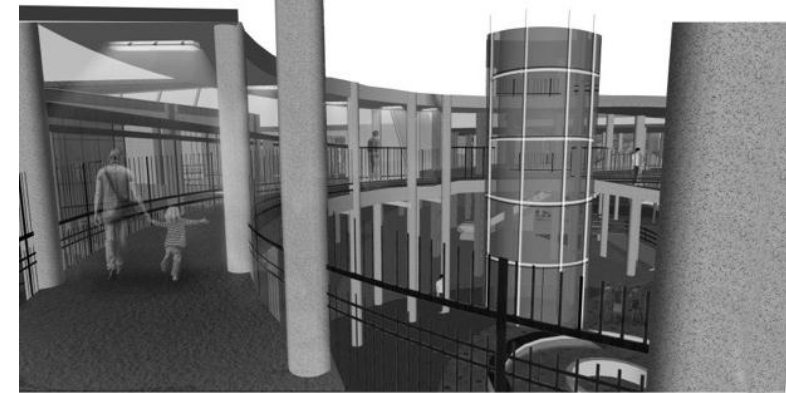

Gambar 11.Perspektif Entrance

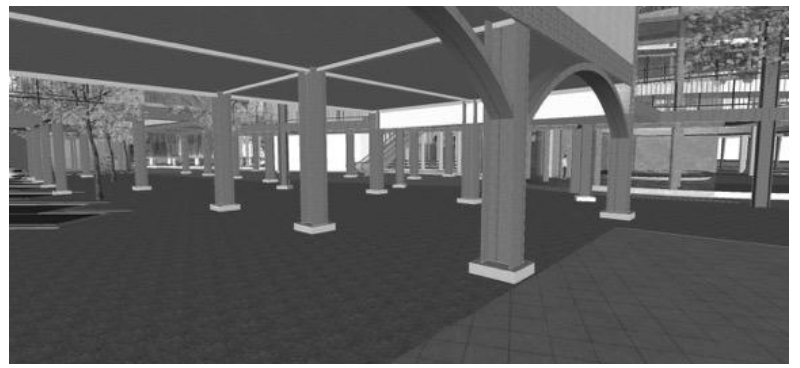

Gambar 12.Perspektif Taman

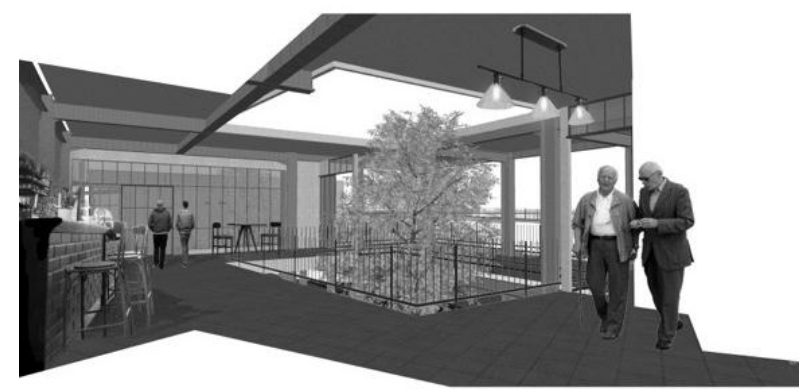

Gambar 13.Perspektif Café

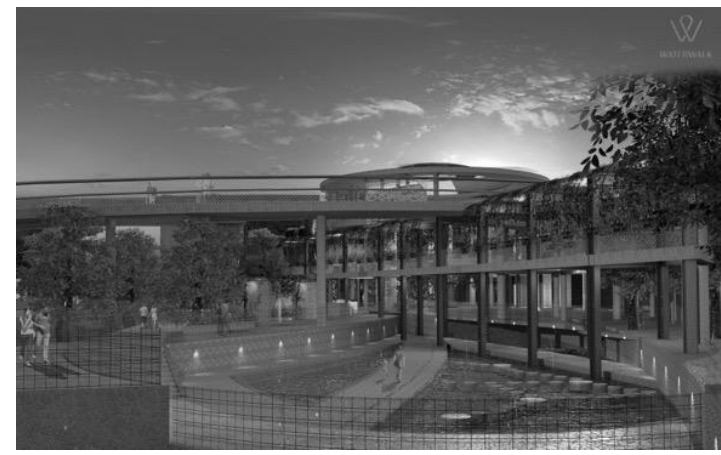

Gambar 14.Perspektif Permainan Air (Kawasan 1)

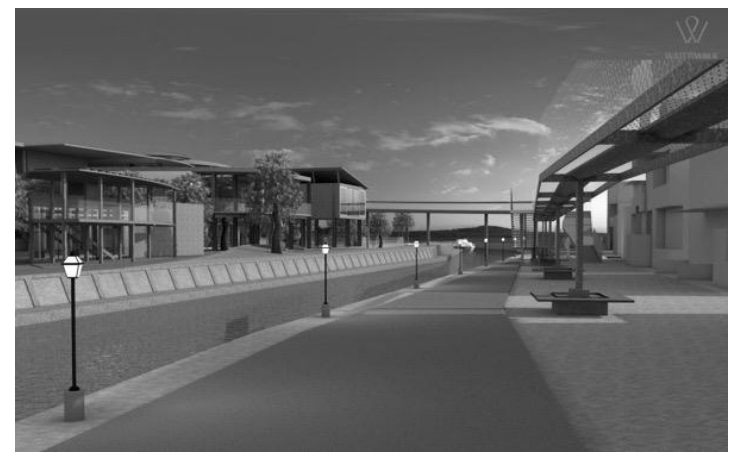

Gambar 15.Perspektif Sirkulasi Bangunan (kawasan II) 